\title{
A REVIEW OF THE GENUS Kingaspis (TRILOBITA, LOWER CAMBRIAN) FROM SPAIN AND ITS BIOSTRATIGRAPHICAL CONSEQUENCES FOR CORRELATION IN THE MEDITERRANEAN SUBPROVINCE
}

\author{
Eladio LIÑÁN $N^{l}$, M. Eugenia DIES $S^{l}$ and \\ Rodolfo GOZALO \\ ' Departamento de Ciencias de la Tierra (Paleontología), Universidad de \\ Zaragoza, E-50009 Zaragoza, Spain.medies@posta.unizar.es \\ 2 Departamento de Geología, Universitat de València, C/ Dr. Moliner 50, E- \\ 46100 Burjasot, Spain.
}

Liñán, E., Dies, M.E. and Gozalo, R. 2003. A review of the genus Kingaspis (Trilobita, Lower Cambrian) from Spain and its biostratigraphical consequences for correlation in the Mediterranean subprovince. [Revisión del género Kingaspis (Trilobita, Cámbrico Inferior) de España y sus implicaciones bioestratigráficas para la correlación en la subprovincia Mediterránea.] Revista Española de Paleontología, 18(1), 3-14. ISSN 0213-6937.

\begin{abstract}
Several specimens of the genus Kingaspis from the Lower Cambrian of Valdoré (León Province), Los Cortijos de Malagón (Ciudad Real Province), Murero, Ateca, Jarque and Tierga (Zaragoza Province) have been revised from a systematic point of view in order to decide their biostratigraphical value and their correlations within the Mediterranean subprovince. After the systematic study, the chronological order was found to be: Kingaspis (Kingaspidoides) velata, Kingaspis (Kingaspidoides) cf. velata and Kingaspis (Kingaspis) campbelli. Kingaspis (Kingaspidoides) velata is typical of the Marianian Stage while $K$. (Kingaspidoides) cf. velata belongs to the upper Marianian?-lower Bilbilian Stage. Kingaspis. $(K$.$) campbelli was found in the upper Bilbilian levels of$ several Spanish localities. This fact facilitates the comparison between Spanish, Moroccan and Jordanian upper Lower Cambrian because this species is present in all these countries.
\end{abstract}

Keywords: Kingaspis, Trilobita, Lower Cambrian, biostratigraphy, Spain, Mediterranean subprovince.

\section{RESUMEN}

En este trabajo se revisa el material del género Kingaspis del Cámbrico Inferior que se ha encontrado en diversas localidades españolas (Valdoré, provincia de León; Los Cortijos de Malagón, provincia de Ciudad Real; Murero, Ateca, Jarque y Tierga, provincia de Zaragoza). La revisión de este material desde el punto de vista sistemático ha permitido calibrar su valor bioestratigráfico y de correlación dentro de la subprovincia Mediterránea. Las especies encontradas son Kingaspis (Kingaspidoides) velata, Kingaspis (Kingaspidoides) cf. velata y Kingaspis (Kingaspis) campbelli. Kingaspis (Kingaspidoides) velata es característica del piso Marianiense, mientras que Kingaspis (Kingaspidoides) cf. velata tiene una distribución Marianiense?-Bilbiliense inferior. Por último Kingaspis (Kingaspis) campbelli ha sido hallada en el Bilbiliense superior en varias localidades de las Cadenas Ibéricas y de la Cordillera Cantábrica; esta presencia permite la comparación entre el Cámbrico Inferior de España, Jordania y Marruecos donde también se ha encontrado la misma especie.

Palabras clave: Kingaspis, Trilobita, Cámbrico Inferior, bioestratigrafía, España, subprovincia Mediterránea. 


\section{INTRODUCTION}

The genus Kingaspis is a common trilobite taxon from upper Lower Cambrian sequences of the Mediterranean region. This is present in Spain (Sdzuy, 1961; Gil Cid and Jago, 1989; Liñán et al., 1993a; Gozalo et al., 1996), Jordan (King, 1923; Rushton and Powell, 1998), Morocco (Termier and Termier, 1950; Gigout, 1951; Hupé, 1953; Geyer, 1990) and Poland (Orlowski, 1964; Lendzion, 1972). Recently Kingaspis has been found in New Brunswick (Canada; Westrop and Landing, 2000).

In Spain, Lotze and Sdzuy (1961) gave the name Kingaspis velatus Sdzuy, 1961 to specimens collected by Richter and Richter (1948) from Huérmeda, in the Iberian Chains. Subsequently, specimens of Kingaspis sp. have been found in Murero (Liñán et al., 1993a; Gozalo et al., 1996), Ateca (Álvaro et al., 1993a), Jarque (Liñán et al., 1996) and other localities of the Iberian Chains. Lotze and Sdzuy (1961) referred some poorly preserved material from Los Cortijos de Malagón (a trilobite locality discovered by Prado [1855] in the Toledo Mountains, Ciudad Real Province) to Kingaspis cf. velatus; and Gil Cid and Jago (1989) also recognised Kingaspis? sp. in this area.

Kingaspis may therefore be useful for correlating different upper Lower Cambrian strata in the Mediterranean subprovince that were affected by the Daroca Regression (Liñán and Gámez-Vintaned, 1993; Álvaro and Vennin, 1998) when large areas emerged during the Bilbilian in some continents (Rushton and Powell, 1998).

The object of this work is the taxonomic revision of new and old material of kingaspidids from several sections (Fig. 1) in northern (Iberian Chains and Cantabrian Mountains) and central Spain (Toledo Mountains) in order to interpret any morphological changes from a stratigraphical point of view and to compare the new data in a Mediterranean context.

\section{SYSTEMATIC DESCRIPTIONS}

The studied material is deposited in the Museo Paleontológico de la Universidad de Zaragoza (Spain) as MPZ 7867, MPZ 7868, MPZ 99/22 to MPZ 99/52, MPZ 99/171 and MPZ 2000/4 to MPZ 2000/140. And in the Münster University (Germany) as L3230. The abbreviations used in the measurements are: $\mathrm{Gw}=$ glabellar width, $\mathrm{Gl}=$ glabellar length, $\mathrm{Cw}=$ cranidial width, and $\mathrm{Cl}=$ cranidial length. The "S" parameter (Liñán Guijarro, 1978, p.158 and fig. 35) makes reference to the imaginary straight line joining the initial and final points of the facial suture.

\section{Superfamily Ellipsocephaloidea Matthew, 1887 \\ Family Ellipsocephalidae Matthew, 1887 \\ Subfamily Ellipsocephalinae Matthew, 1887 Genus Kingaspis Kobayashi, 1935}

Type species: Anomocare campbelli King, 1923; by original designation.

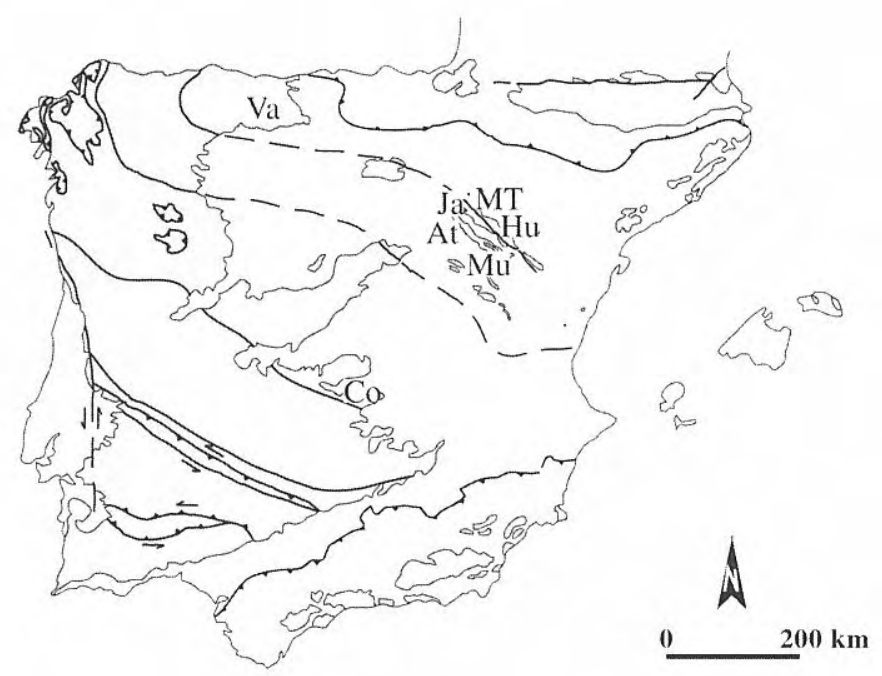

Figure 1. Iberian Peninsula showing the Pre-Hercynian outcrops and the location of the studied sections. At: Ateca; Co: Cortijos de Malagón; Hu: Huérmeda; Ja: Jarque; MT: Tierga; Mu: Murero; Va: Valdoré.

\section{Discussion}

Kobayashi (1935) assigned Kingaspis to the subfamily Ellipsocephalinae. Later, Richter and Richter (1941) placed it close to the genus Palaeolenus Mansuy, 1912, but Hupé (1953) noted certain differences between them. According to Hupé, Kingaspis has a shorter and less well-defined glabella and its eye ridge is barely defined. Hupé established the subfamily Kingaspidinae and two subgenera: Kingaspis (Kingaspidoides) with, and K. (Kingaspis) without, an occipital spine. Geyer (1990, p. 333) proposed to turn these subgenera into genera in base of several characters which, in our opinion, do not make easy the distinction of both genera in his emended diagnosis. Geyer's emended diagnosis is difficult to apply in distorted material which is very common in Cambrian rocks. According to Rushton and Powell (1998) the main character of Kingaspidoides to be distinguished from Kingaspis is the relatively uneven convexity of the cranidium in the transverse section.

Among the Spanish specimens, there are two different morphologies which coincide with the Kingaspis and Kingaspidoides species differenciated in the material figured from Morocco by Geyer (1990) and from Jordan by Rushton and Powell (1998). The morphology A shows a preocular-preglabellar furrow that defines a distinct frontal area which is not present in the type species of Kingaspis campbelli (King, 1923). We interpret this morphology as typical of Kingaspidoides. Morphology B (or Kingaspis type) has not a preocular-preglabellar furrow. In the present state of knowledge, we prefer to consider Kingaspis and Kingaspidoides as subgenera.

\section{Subgenus Kingaspis (Kingaspidoides) Hupé, 1953}

Type species: Kingaspis (Kingaspidoides) armatus Hupé, 1953 [=Kingaspis (Kingaspis) brevifrons Hupé, 1953]. 


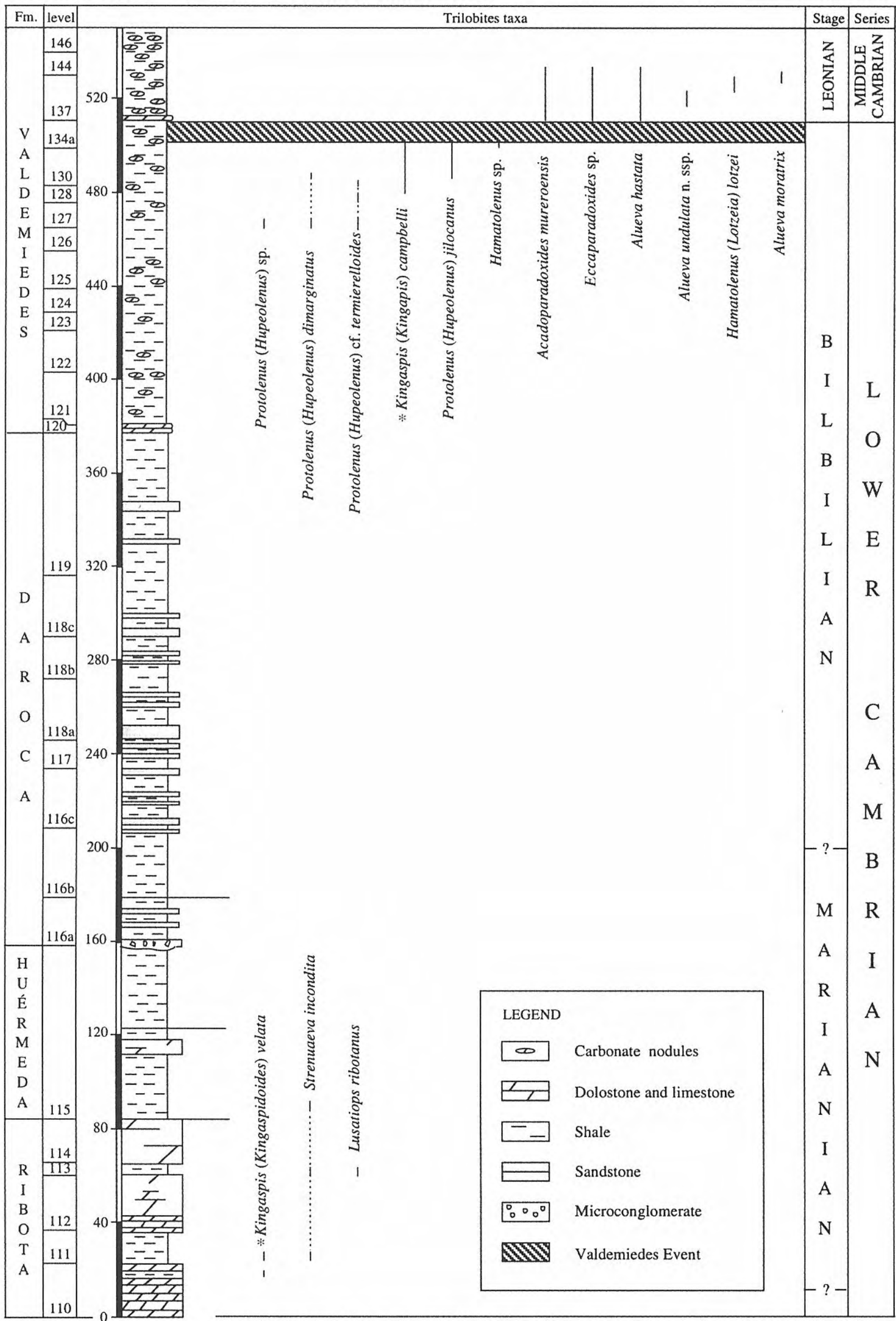

Figure 2. Stratigraphic distribution of trilobite taxa in section Jarque 1 (modified from Liñán et al., 1996). * Studied taxa. 
Kingaspis (Kingaspidoides) velata Sdzuy, 1961

Figs. 3 a, b, e

1929 Agraulos sp.; Lotze, p. 27.

v 1948 Ellipsocephalidae, gen. et sp. indet.; Richter and Richter, 34, pl. 1 figs. 9-11.

v 1958 Palaeolenus velatus n. sp. (Sdzuy, manuscr.); Lotze, 730.

v* 1961 Kingaspis velatus n. sp.; Sdzuy, 308-310, pl. 15, figs. 1-8.

Emended name: The suffix -aspis (as in Kingaspis) is feminine, so the correct binomen is Kingaspis velata (Dr. Dean, p. com.) referring to the concealed relief.

Material and localities: Two cranidia preserved as tectonically distorted internal moulds in green lutites from the Jarque 1 section (Zaragoza province; Fig. 2). Sdzuy's holotype (Fig. 3a, e) comes from the Huérmeda section and is housed in the Geologisch-Paläontologisches Museum of Münster (Germany), number L3230.

Measurements: The best preserved cranidium (Fig. 3 b) exhibits the following proportions: $\mathrm{Gw} / \mathrm{Cw}=1 / 2, \mathrm{Gl} / \mathrm{Cl}=$ $4 / 5$.

\section{Description}

Cranidium subrectangular, slightly transversally convex, characterised by an arch-like anterior margin. The preglabellar field and the smooth preocular area lie below the levels of the glabella and eye. Subquadrate to subconical glabella with anterior and lateral furrows; anterolateral corners not expanded. Some of the specimens have three pairs of non-transglabellar furrows bent slightly backwards. Occipital furrow wide and well marked, occipital ring rounded and extended posteriorly. Eye ridges constant in width, but not always well defined. Palpebral lobe approximately as long as the anterior and posterior branches of the facial suture. Wide (sag.) posterior border furrow in the fixigena bent slightly forward. Thorax and pygidium unknown.

\section{Remarks}

For discussion see Sdzuy (1961), who founded his new species $K$. velatus (now $K$. velata) based on a high number of cranidia from Huérmeda locality (Iberian Chains) with a glabella approximately half the cranidial width, the lateral margins of the glabella convergent forward, and an occipital ring wider (sag.) medially than laterally.

Kingaspis (Kingaspidoides) velata shows the diagnostical character of Kingaspidoides. This species differs from those from Morocco described by Geyer (1990) as Kingaspidoides because the Spanish species has not an anterior border marked. It differs also from Kingaspidoides cf. obliquoculatus from New Brunswick (Westrop and Landing, 2000) because the Avalonian North American specimens have an interocular fixigenae that slopes down less steeply to the palpebral lobes.

Stratigraphical distribution: Levels 110 and 111 of the Jarque 1 section in the middle part of the Ribota Formation (Fig. 2), and in the Huérmeda section at the top of the Ribota Formation (Lotze, 1961, fig. 6).

\section{Kingaspis (Kingaspidoides) cf. velata Sdzuy, 1961}

Fig. 3c, d, f, g, i, j

v 1961 Kingaspis cf. velatus n. sp.; Sdzuy, 592, pl. 15, figs. 9-14.

? 1989 Kingaspis ? sp.; Gil Cid and Jago, 93-94, pl. 1, figs. $1-8$.

Material and localities: Eight poorly preserved tectonically distorted cranidia in yellow sandstones (Los Cortijos de Malagón) and red lutites (Tierga). The samples were collected from the Los Cortijos de Malagón site (Ciudad Real province) and from an unpublished section at Tierga (Zaragoza province).

Measurements: Measurements for the largest cranidium (MPZ 99/28) are: $\mathrm{Cl}=14 \mathrm{~mm}, \mathrm{Gl}=10 \mathrm{~mm}, \mathrm{Gw}=6 \mathrm{~mm}$. The best preserved cranidium (Fig. 3j) exhibits the following proportions: $\mathrm{Gw} / \mathrm{Cw} \simeq 2 / 5, \mathrm{Gl} / \mathrm{Cl}=5 / 7$.

\section{Description}

Cranidium smooth, very similar to Kingaspis (Kingaspidoides) velata, but with an anterior margin more convex (trans.) and a moderately marked anterior border furrow; this border is approximately $1 / 3$ of the preglabellar field's width (sag.). Preglabellar field convex with one preglabellar-preocular furrow. Palpebral lobes curved,

Figure 3. Bar $=1 \mathrm{~mm}$. a, b, e: Kingaspis (Kingaspidoides) velata Sdzuy, 1961. a, e: Holotype. Latex cast. Internal mould of cranidium (original specimen figured by Sdzuy, 1961: Tafel 15, Fig. 4). Huérmeda (Zaragoza province). L3230; a: dorsal view, e: frontal view. b: internal mould of cranidium. Jarque (Zaragoza province). MPZ 99/22. c, d, f, g, i, j: Kingaspis (Kingaspidoides) cf. velata Sdzuy, 1961. c, d: Internal mould of cranidium. Los Cortijos de Malagón (Ciudad Real province). MPZ 99/27; c: dorsal view; d: lateral view. f, g, i: Internal mould of cranidium. Tierga (Zaragoza province). MPZ 99/25; f: lateral view; g: dorsal view; i: frontal view. j: Internal mould of cranidium. Los Cortijos de Malagón (Ciudad Real province). MPZ 99/28. Dorsal view. h, k: Kingaspis (Kingaspidoides) sp. Internal mould of cranidium. Murero (Zaragoza province). MPZ 99/52; h: dorsal view; k: lateral view. l-r: Kingaspis (Kingaspis) campbelli (King, 1923); 1, o, r: cranidium. Valdoré (León province). MPZ 2000/8; 1: dorsal view; o: frontal view; r: lateral view. m: Partly exfoliated cranidium. Valdoré (León province). MPZ 2000/7. Dorsal view. n, q: Cranidium. Ateca (Zaragoza province). MPZ 7867; n: dorsal view; q: lateral view. p: Internal mould of cranidium. Murero (Zaragoza province). MPZ 99/39. Dorsal view. 

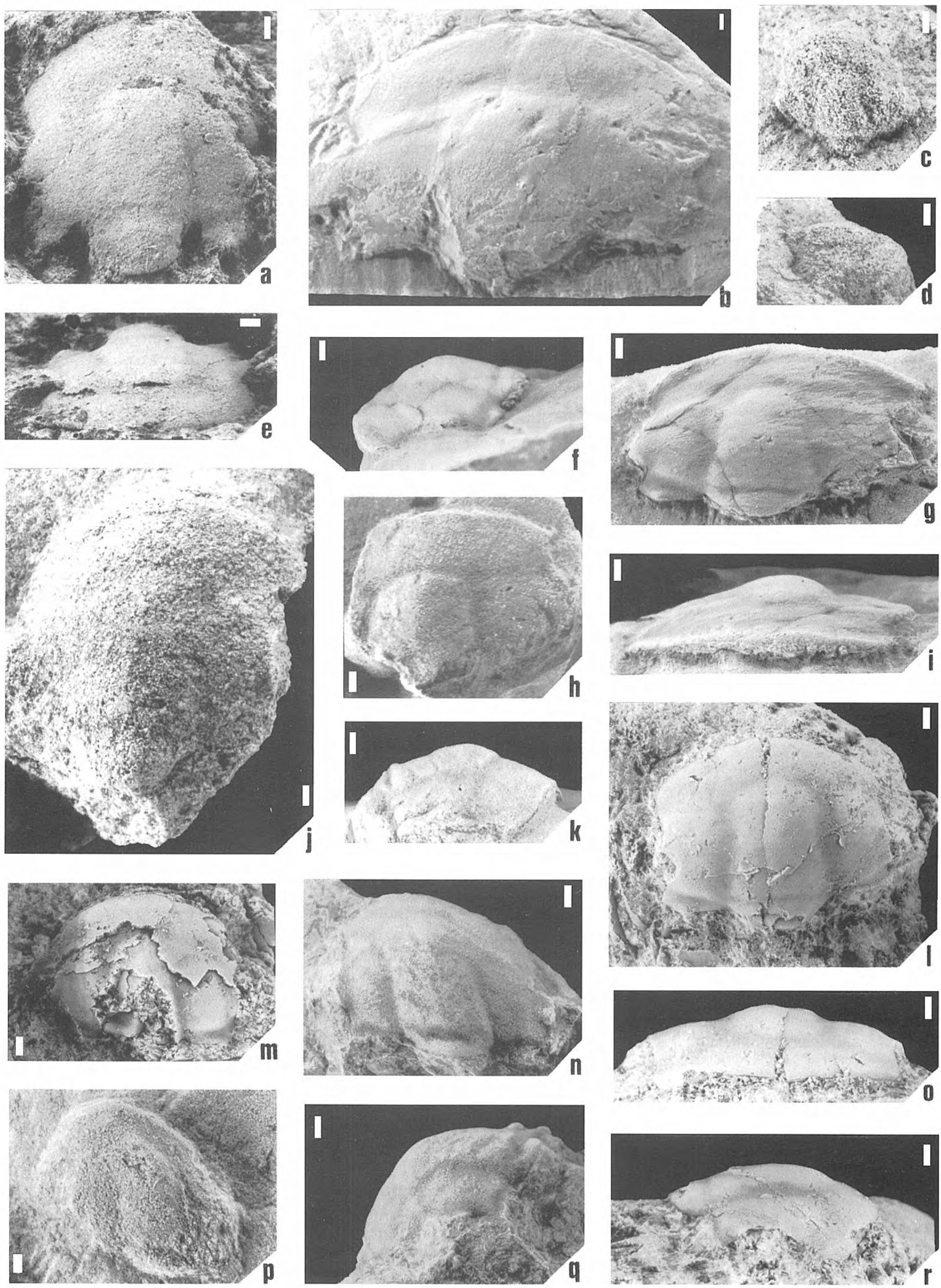
subparallel to the sagittal axis. Smooth, convex glabella. Deep posterior border furrow. Occipital ring triangular with long area depressed (sag.) below the glabella level. Thorax and pygidium unknown.

Remarks: Sdzuy (1961) assigned the material from Los Cortijos de Malagón to Kingaspis cf. velatus. The new specimen from Tierga is included in open nomenclature together with the specimens from Los Cortijos de Malagón because of the scarce number of samples.

Stratigraphical distribution: Lower part of the Huérmeda Formation at the Tierga section, and upper part of Los Cortijos Formation from Los Cortijos de Malagón site.

\section{Kingaspis (Kingaspidoides) sp. Fig. 3h, k}

Material and locality: one cranidium preserved in green lutites as internal mould from Murero (Rambla de Valdemiedes 2 section). MPZ 99/52.

\section{Description}

Cranidium arch-like anterior margin in frontal view and slightly convex in dorsal view. Smooth preglabellar field (directly connected to the anterior margin) and of $1 / 3$ of the cranidium length (sag.). Glabella with marked lateral and anterior furrow, parallel sides, and expanded anterolateral corners. Four pairs of slightly marked non-transglabellar furrows directed backward. Deep and rectangular occipital furrow. The only sample is broken so that we cannot see completely the occipital ring. Smooth preocular field as wide as the preglabellar field (sag.). Marked preocularpreglabellar furrow. Long palpebral lobe joint to the anterior corner of the glabella by a slightly curved eye ridge and directly joint to the posterior border so that it has not postocular field. Subtrapezoidal and smooth palpebral field. "S" parameter (Liñán Guijarro, 1978) secant and slightly convergent. Thorax and pygidium unknown.

\section{Remarks}

Kingaspis (Kingaspidoides) sp. differs from the Moroccan species in the lack of anterior border.

Stratigraphical distribution: This specimen was found removed in the upper part of the Valdemiedes Formation (upper Bilbilian-early Leonian), and it is the youngest Kingaspidoides found in Spain.

Subgenus Kingaspis (Kingaspis) Kobayashi, 1955

Type species: Anomocare campbelli King, 1923

Kingaspis (Kingaspis) campbelli (King, 1923) Figs. 31-r, 4.

* 1923 Anomocare campbelli sp. nov.; King, 511-514, fig. $3,4 \mathrm{~b}$. v 1990 Kingaspis campbelli (King, 1923); Geyer, 104, pl. 15 fig. 11, pl. 17 fig. 8-10 (with previous full synonymy).

v 1993a Kingaspis sp.; Liñán et al., fig. 3.

v 1993a Kingaspis sp.; Álvaro et al., 44-46, pl. 1 figs. 5-6.

v 1996 Kingaspis sp.; Gozalo et al., fig. 34.

1998 Kingaspis campbelli (King, 1923); Rushton and Powell, 141, fig. 21-26.

v 1999 Kingaspis campbelli (King, 1923); Dies et al., 223-225, fig. 1 .

Material and localities: The material from the Iberian Chains includes three almost complete specimens, one hundred and thirty-eight cranidia and three librigenae preserved in green lutites as internal moulds, and some external moulds from the Jarque 1 section (Zaragoza province); eleven cranidia, two cranidia attached to incomplete thoraces and one cephalon preserved in green and yellow lutites as internal moulds showing traces of the organic carapace and some of their external moulds, from the Rambla de Valdemiedes 1 and 2 sections (near Murero, Zaragoza province); one cranidium preserved in grey limestone from the Ateca section (Zaragoza province); all tectonically distorted. In the Cantabrian Mountains, five cranidia preserved within limestone pebbles from the Valdoré section (León province).

All the collected material belongs to the Hamatolenus ibericus zone (Liñán et al., 1993a), Upper Bilbilian, according to the trilobite assemblages. Therefore the high number of Spanish specimens studied (more than 150) permits a better knowledge of the intraspecific variation of $K$. (K.) campbelli.

Measurements: The largest cranidium (Fig. 4e, f) has the following proportions: $\mathrm{Gw} / \mathrm{Cw}=1 / 2, \mathrm{Gl} / \mathrm{Cl} \simeq 3 / 4$; and for the smallest one (Fig. $4 \mathrm{~g}, \mathrm{~h}$ ): $\mathrm{Gw} / \mathrm{Cw}=1 / 2, \mathrm{Gl} / \mathrm{Cl} \simeq 3 / 4$. These parameters, calculated in 119 Spanish specimens, are represented in the figure 5 together with those from the lectotype (King, 1923), Morocco (Geyer, 1990) and Jordan (Rushton and Powell, 1998). The lectotype coincides with the regression line that results from the Spanish material measurements.

\section{Description}

Cranidium - See Geyer (1990: 104). The librigena shows pointed genal spines (as in Kingaspis cf. sarhroensis Geyer, 1990) reaching at least as far as the third axial ring. Thorax with up to fourteen thoracic segments. In the first five segments the rachys is distinctly wider than the pleura and, in the following segments, the axis is approximately as wide as the pleura. The pleura are bent by the fulcral line and have wide and leaf-shaped pleural furrows. An eroded pygidium attached to an almost complete specimen (Fig. 4a, d) exhibits semicircular shape with only one noticeable axial and pleural furrow. The ratio between the width of the pleural field in the pygidium and the axis (trans.) is $1 / 2$.

The grade of effacement is different between the interior and exterior of the exoskeleton. In the internal mould, the furrows are more marked than in the external mould as it is also evident in the material from Jordan (Rushton and Powell, 1998). 

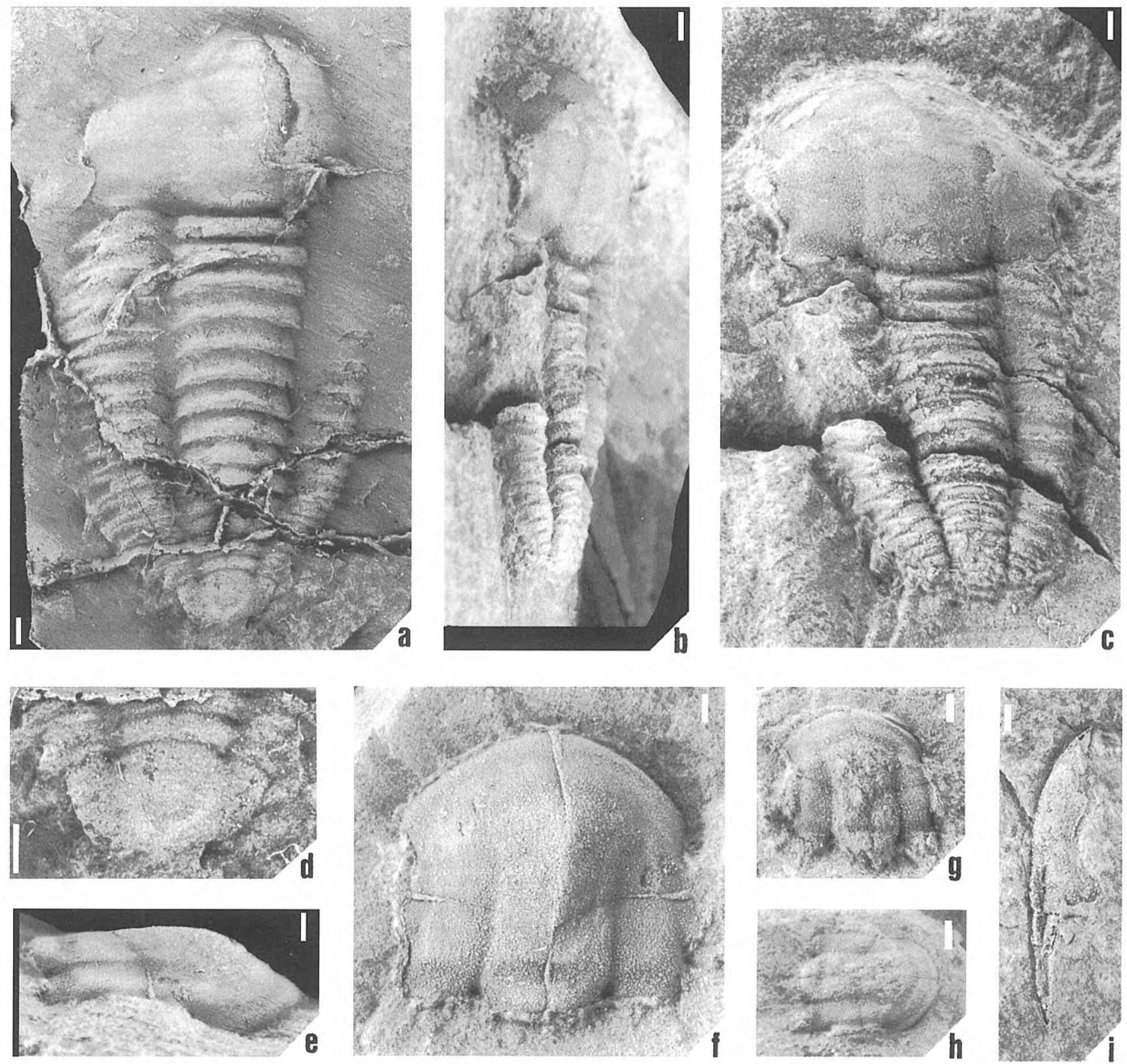

Figure 4. Kingaspis (Kingaspis) campbelli (King, 1923). Bar = $1 \mathrm{~mm}$. Jarque (Zaragoza province). Internal moulds. a, d: Latex cast. MPZ 2000/10. Dorsal view; a: complete specimen showing the pygidium (partly incomplete due to erosion); d: enlarged view of the pygidium. b, c: Almost complete specimen. MPZ 99/37; b: lateral view; c: frontal view. e, f: cranidium. MPZ 99/34; e: lateral view; f: dorsal view. g, h: cranidium of a juvenile. MPZ 99/36; g: dorsal view; h: lateral view. i: librigena.

\section{Ontogeny and variability}

The best preserved immature cranidia (Fig. 4g-h) have a well-defined glabella and are not so convex transversally as the adult cranidia. Furthermore, they show a preglabellar-preocular furrow as well as marked glabellar furrows that are not always present in adults.

In the internal mould, the adult specimens show an intraspecific variability from a smooth cranidium with only a partially defined glabella (Fig. 3p) to a welldefined anterior border, glabella and glabellar furrows (Fig. 3n, q and Fig. 4e, f). This variability includes transitional specimens (Fig. 4b, c) without an anterior border but with well-defined glabellar furrows as in the Jordan material (Rushton and Powell, 1998: Figs. 21a, $25 \mathrm{a}$ and 23a).

There are also some differences in the relative length of the palpebral lobe. A morphotype can be distinguished because it has a palpebral lobe slightly longer than the posterior branch of the facial suture; the other is characterised by a palpebral lobe approximately as long as the posterior branch of the facial suture. This feature is also present in the material figured by Rushton and 


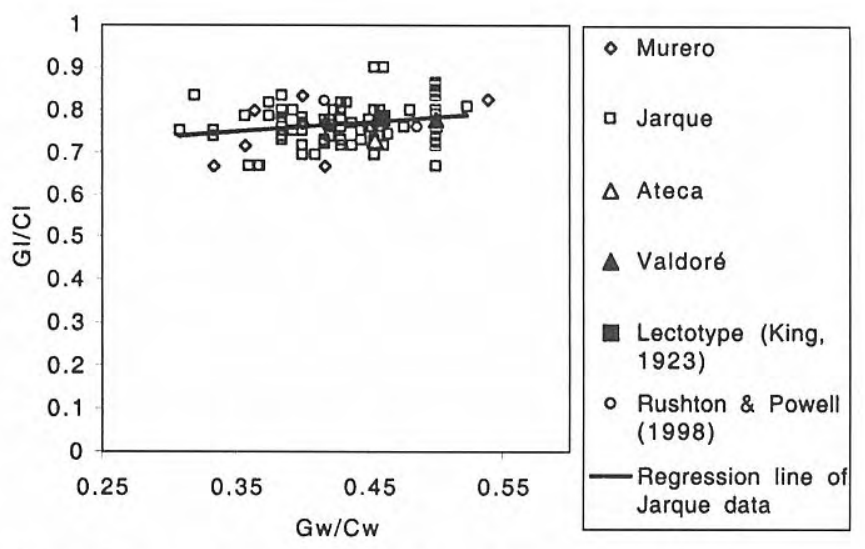

Figure 5. Glabellar length/Cranidial length ratio against Glabellar width/Cranidial width ratio for Kingaspis (Kingaspis) campbelli (King, 1923). The regression line has been obtained on the basis of measurements on the specimens from section Jarque 1 .

Powell (1998) where appears to be a function of the size of the cranidia, but is not clear in the Spanish specimens where the size is similar in both morphotypes.

\section{Remarks}

The Spanish cranidia exhibit features similar to the specimens described by Geyer (1990) and Rushton and Powell (1998) for the topotype material. The exfoliated cranidium shows a thin, rounded anterior border of constant width as in the lectotype and some of the topotypes described by Rushton and Powell (1998) which is not noticeable on the external surface of the cephalon. The two pygidia assigned to Kingaspis campbelli by Rushton and Powell (1998) show three (fig. 22) and four (fig. 26) well-marked axial and pleural segments while in the Spanish pygidium there is only one. Other difference is the ratio between the axis width and the pleural field width (trans.) which is approximately 1 in the Jordan specimens while in the Spanish one is approximately $1 / 2$. These differences may be interpreted as preservational because the pleural field in the Spanish pygidium is bent (sag.).

Stratigraphical distribution: In the Iberian Chains $K$. $(K$.) campbelli occurs in levels 129 to 134 of the Jarque 1 section (Fig. 2), levels 1 to 5 of the Rambla de Valdemiedes 1 section, levels 1 to 3 of the Rambla de Valdemiedes 2 section and level 16 of the Ateca 16 section (see Álvaro et al., 1993a); all of them in the middle part of the Valdemiedes Formation. In the Cantabrian Mountains, the species occurs in the base of the upper member of the Láncara Formation (see Zamarreño, 1972; fig. 42).

\section{STRATIGRAPHY}

The material studied here was collected in the Iberian Chains (Jarque, Ateca, Tierga and Murero sections), the Cantabrian Mountains (Valdoré) and the Toledo Mountains (Los Cortijos de Malagón site).
The Jarque 1 section is one of the most complete Cambrian sequences in the Iberian Chains (Liñán et al., 1996). Upper Lower Cambrian strata are represented by the dolomite and marble alternations of the Ribota Formation, the shale and fine sandstone of the Huérmeda Formation, alternations of shale and sandstone (Daroca Formation) and alternations of shale and carbonate nodules of the Valdemiedes Formation (Fig. 2). The specimens assigned here to Kingaspis (Kingaspidoides) velata were found in the middle part of the Ribota Formation. This agrees with previous data on the species which was originally reported by Lotze and Sdzuy (1961) from the top of the Ribota Formation at Huérmeda, a locality near the Jalón valley. The youngest species, Kingaspis (Kingaspis) campbelli, is recorded from the middle part of the Valdemiedes Formation.

Near Tierga, specimens of Kingaspis (Kingaspidoides) cf. velata in the lower part of the Huérmeda Formation represent the earliest stratigraphical position of this taxon in the Iberian Chains.

At Murero, the material now assigned to $K$. (Kingaspis) campbelli derives from the middle part of the Valdemiedes Formation at the base of the sections Rambla de Valdemiedes 1 and Rambla de Valdemiedes 2 (Liñán and Gozalo, 1986; Liñán et al., 1993a; Gozalo et al., 1996), the same stratigraghical position as in the Ateca section (Álvaro et al., 1993a).

In the Valdoré section, K. (Kingaspis) campbelli was found within pebbles in the conglomeratic base of the upper member of the Láncara Formation.

Los Cortijos de Malagón section was studied by Weggen (1955) who distinguished five stratigraphic units within the Los Cortijos Sandstone. These were recognised by Zamarreño et al. (1976) as follows: Unit 1, bright green argillite (base); Unit 2, green sandstone with abundant shale; Unit 3 consisting of a sandstone-shale alternation; Unit 4, quartzite; and Unit 5, trilobitic sandstone (top). The trilobites described herein as Kingaspis (Kingaspidoides) cf. velata were collected from the lower part of the Unit 5. Given that the Los Cortijos Formation was tentatively correlated with the Daroca Formation of the Iberian Chains by Sdzuy (1971) and Liñán et al. (1993b), the specimens from Los Cortijos de Malagón are probably stratigraphically higher than those now reported from Tierga (Iberian Chains).

\section{BIOCHRONOLOGY}

The position of the Lower-Middle Cambrian boundary is still a controversial subject studied by the International Subcommission on Cambrian Stratigraphy (Sdzuy, 1971; Geyer and Palmer, 1995; Rushton and Powell, 1998; Geyer and Shergold, 2000). We adopt herein the classic boundary used in the Mediterranean subprovince that is placed at the first appearance datum (FAD) of Acadoparadoxides (=Eoparadoxides) mureroensis (Sdzuy, 1958). This formal aspect will allow us to employ the regional Stages of Spain (Sdzuy, 1971; Liñán et al., 1993b) which are considered, at present, by 


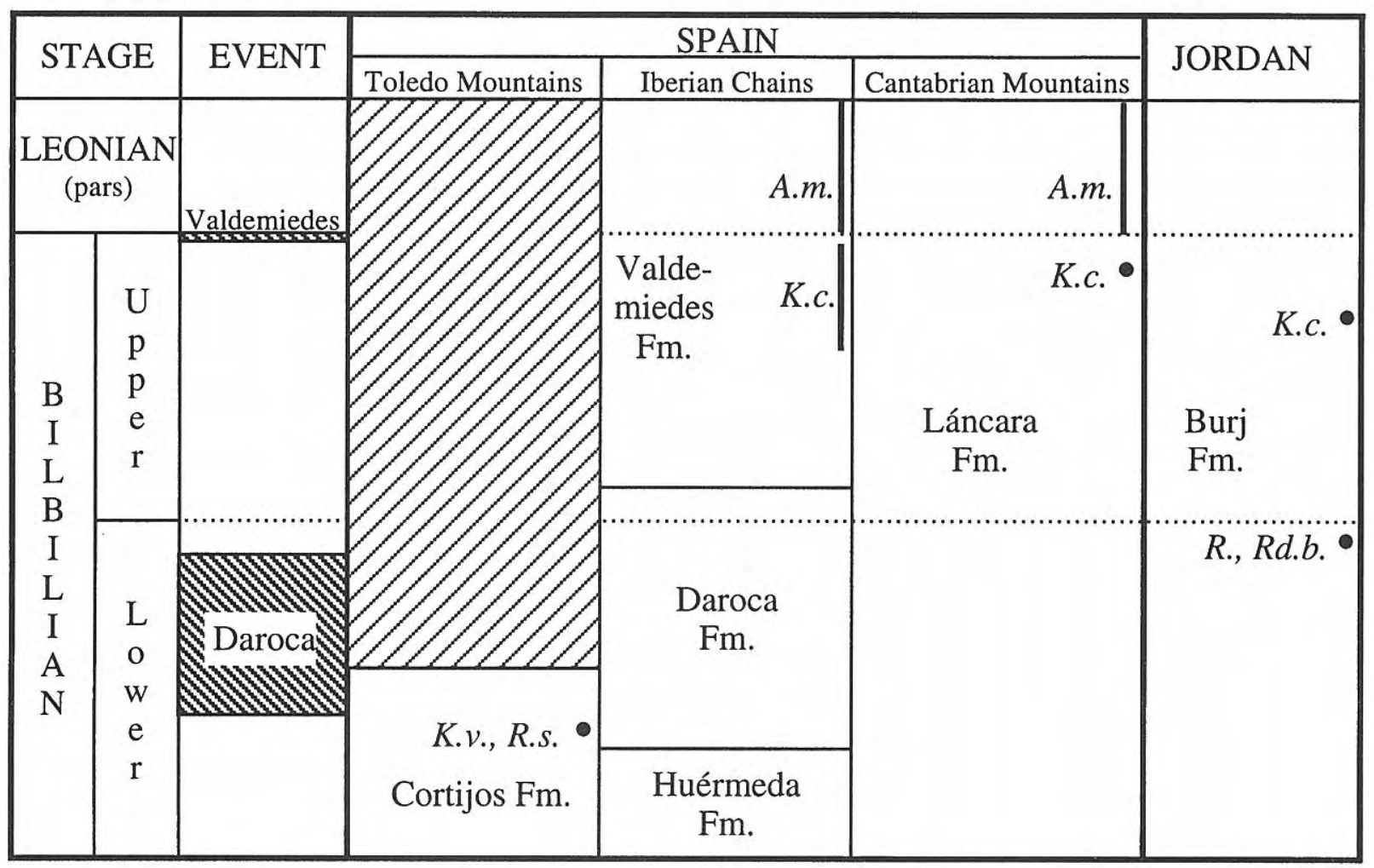

Figure 6. Comparison between distributions of the Spanish and Jordan taxa herein described. K. c. : Kingaspis (Kingaspis) campbelli; K. v. : Kingaspis (Kingaspidoides) cf. velata; R. s.: Realaspis strenoides; R.: Realaspis sp. nov.; Rd. b.: Redlichops blankenhorni; A. m.: Acadoparadoxides mureroensis.

Sdzuy et al. (1999) as the most useful units for the Mediterranean subprovince correlation.

Kingaspis (Kingaspidoides) velata Sdzuy, 1961 was cited by Lotze (1961) associated with Lusatiops ribotanus Richter and Richter, 1948 and the FAD of Strenuaeva incondita Sdzuy, 1961 in the Huérmeda section. This assemblage characterises the Marianian Stage (Sdzuy, 1971; Liñán et al., 1993b). In the Ribota Formation at the Jarque 1 section, K. (Kingaspidoides) velata occurs with $S$. incondita and immediately below L. ribotanus and the presence at the base of the overlying Huérmeda Formation of a Middle-Upper Marianian trilobite assemblage, including Andalusiana, L. ribotanus, Triangulaspis and Micmacca aff. coloi (see Sdzuy, 1971; Liñán et al., 1993 b) at several localities in the Iberian Chains confirms this biochronological interpretation.

In Los Cortijos de Malagón, Kingaspis (Kingaspidoides) cf. velata is associated with Realaspis strenoides Sdzuy, 1961, Pseudolenus weggeni Sdzuy, 1961, Pseudolenus glaber Sdzuy, 1961 (Lotze and Sdzuy, 1961) and cf. Latoucheia sp. (Gil Cid and Jago, 1989) of lower Bilbilian age (Sdzuy, 1971; Liñán et al. 1993b). As Kingaspis (Kingaspidoides) cf. velata is also recorded in the lower part of the Huérmeda Formation, the specimens from Tierga may still be of Marianian age. Thus, an Upper Marianian-Lower Bilbilian range for this taxon is indicated.

Kingaspis (Kingaspis) campbelli (King, 1923) is found together with Protolenus (Hupeolenus) cf. termierelloides Geyer, 1990, Protolenus (Hupeolenus) jilocanus (Liñán and Gozalo, 1986) and Protolenus (Hupeolenus) dimarginatus Geyer, 1990 at the Jarque 1 section (Liñán et al., 1996; Dies et al., 2001); it is now reported together with $P$. $(H$.) jilocanus from Ateca (Alvaro et al., 1993a) and with Hamatolenus (Hamatolenus) ibericus Sdzuy, 1958, P. (H.) jilocanus, Onaraspis altus (Liñán and Gozalo, 1986), Tonkinella sequei Liñán and Gozalo, 1999, Sdzuyia sanmamesi Liñán and Gozalo, 1999 and Hamatolenus (Myopsolenus?) sp. at the Rambla de Valdemiedes 1 and 2 sections (Liñán and Gozalo, 1986, 1999; Gozalo et al. 1996). These record suggest an Upper Bilbilian age for the species Kingaspis (Kingaspis) campbelli (King, 1923) in Spain. A Bilbilian age has also been inferred for the trilobite levels with Kingaspis (Kingaspis) campbelli from the Wadi Zarqa Ma'in section in Jordan and with doubt from Morocco by Rushton and Powell (1998).

\section{KINGASPIS (KINGASPIS) CAMPBELLI CORRELATION}

Kingaspis (Kingaspis) campbelli occurs in Jordan (Burj Formation, Wadi Zarqa Ma'in; see Rushton and Powell, 1998), Morocco (Jbel Wawrmast Formation, Boukaïs; see Geyer, 1990) and Spain (Valdemiedes Formation, Jarque, Murero and Ateca; and Láncara Formation, Valdoré; herein).

The Jordanian specimens of Kingaspis (Kingaspis) campbelli belong to the uppermost part of the Numayri 


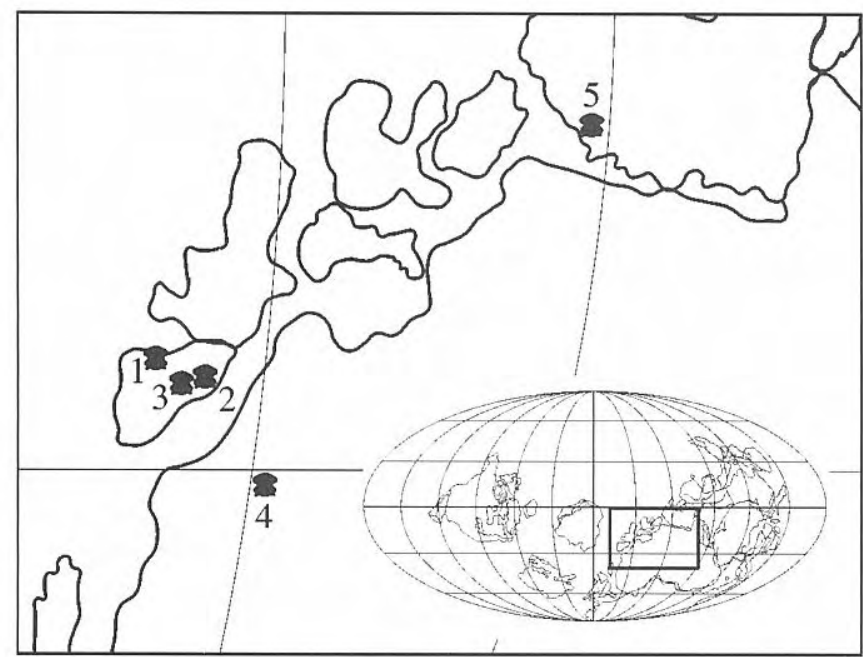

Figure 7. Palaeogeographical distribution of Kingaspis $(K$.) campbelli (King, 1923) in the Mediterranean subprovince. 1: Cantabrian Mountains (Spain), 2: Iberian Chains: Mesones Unit (Spain), 3: Iberian Chains. Badules Unit (Spain), 4: Western AntiAtlas (Morocco) and 5: Dead Sea (Jordan). Paleogeography modified after Pillola (1990).

Dolomite Member and/or the Hanneh Siltstone Member within the Burj Formation (Rushton and Powell, 1998: 134). This species is associated with Palaeolenus antiquus (Chernysheva, 1956) which characterises the basal Zone of the Amgan Stage in Siberia. Rushton and Powell (1998: table 1) correlated it with the Bilbilian Stage. Nevertheless, their correlation with the Siberian Stages is slightly different from that of Sdzuy (1995) and Sdzuy et al. (1999) emphasising the lack of biochronological knowledge in the upper Lower Cambrian.

The upper part of the Numayri Dolomite Member also contains Redlichops blanckenhorni Richter and Richter, 1941 and Realaspis sp. nov. sensu Rushton and Powell, 1998 in Wadi Ounai at the southern edge of Dead Sea (see op. cit.: Fig. 2). These authors suggest a Bilbilian age for this fauna.

A comparison of Jordan faunas (Fig. 6) with classic and new kingaspidid taxa from Spain permit us to tentatively propose a Lower Bilbilian-lower Upper Bilbilian age for the Redlichops blanckenhorni and Realaspis sp. nov. faunas and an Upper Bilbilian age for the Kingaspis (Kingaspis) campbelli and Palaeolenus antiquus faunal assemblages.

The Moroccan specimens of $K$. (Kingaspis) campbelli are from the Jbel Wawrmast Formation (probably Breche à Micmacca Member), but their exact stratigraphical level is unknown (see Geyer, 1990: 44; and Rushton and Powell, 1998: 137). The assemblages at these levels include $K$. (K.) campbelli, Ornamentaspis destombesi Geyer, 1990 and Ornamentaspis? sp. A sensu Geyer, 1990 and regarded as part of the Ornamentaspis frequens Zone (Geyer, 1990; Rushton and Powell, 1998), correlated with the middle Leonian Stage by Geyer (1990) and Sdzuy et al. (1999). The new biostratigraphic data from Spain indicate that $K$. (Kingaspis) campbelli is not limited to the Moroccan equivalents of the Leonian Stage, but ranges up from the Bilbilian levels in Spain and Jordan.

\section{SUMMARY AND CONCLUSIONS}

Our review of the available material of the genus Kingaspis from the Iberian Chains and Toledo Mountains places both subgenera $K$. (Kingaspidoides) and $K$. (Kingaspis) in equivalent Lower Cambrian sequences in Spain. Four kingaspidid taxa are included in this study. The former Kingaspis velatus and Kingaspis cf. velatus, originally described by Sdzuy (1961), are now placed in the subgenus K. (Kingaspidoides), sensu Geyer (1990); Kingaspis (Kingaspis) campbelli is recognised as the species known in Jordan and Morocco and permits a better correlation of the upper Lower Cambrian of the Mediterranean subprovince.

Kingaspis (Kingaspidoides) velata is reported from the Ribota Formation characterising a Middle-Upper Marianian Stage in the Iberian Chains. Kingaspis (Kingaspidoides) cf. velata, in the Los Cortijos Formation (Toledo Mountains) is now known from the Huérmeda Formation (Iberian Chains) and its trilobite association suggests an uppermost Marianian? and Lower Bilbilian age. Kingaspis (Kingaspis) campbelli is cited herein from several Spanish localities in the Iberian Chains and Cantabrian Mountains, where it occurs in the middle part of Valdemiedes Formation and in the basal beds of the upper member of the Láncara Formation respectively; an upper Bilbilian age for this species is indicated by its trilobite association.

At present, Kingaspis $(K$.$) campbelli is the first$ Cambrian species common to Jordan and Spain allowing a more accurate correlation in upper Bilbilian times (Fig. 6). Rushton and Powell (1998) correlated the Burj Formation with the Bilbilian Stage by means of the recorded trilobites, suggesting that the Daroca Regression probably re-established fluvial deposition over Jordan and on the Arabian Craton, an opinion with which we agree. If our biostratigraphical conclusions are correct, a more exact correlation is now possible with the Wadi Zarqa Ma'in area in the Northern Dead Sea, where we consider that the fluvial Hanneh Silstone Member has a similar biostratigraphical position in the upper part of the Valdemiedes Formation. Furthermore we cannot discard the possibility that the fluvial Hanneh Silstone Member includes the Valdemiedes Event (Liñán et al., 1993a), which was the last regressive pulse of the generalized Daroca Regression in upper Lower Cambrian.

\section{ACKNOWLEDGEMENTS}

This work is a contribution to projects PB96-0744 of the Dirección General de Estudios Superiores, BTE 2000-1145C02-01 of the Dirección General de Investigación, 121/99 and 166/99 of the Departamento de Educación y Cultura del Gobierno de Aragón. M. E. Dies holds a pre-doctoral 
research grant from the Departamento de Educación y Cultura del Gobierno de Aragón. Dr. Markus Bertling allowed us to study the Kingaspis (Kingaspidoides) velata holotype and Dr. Karsten Weddige allowed us the revision of the Senckenberg Museum collection of Kingaspis. Photography by Servicio de Fotografía de la Universidad de Zaragoza. Comentaries to original manuscript were made by Dr. Álvaro, Dr. Arbizu, Mr. Gámez Vintaned, Dr. Geyer, Dr. Fletcher, Dr. Martínez Chacón and Dr. Villas. The authors wish to thank the following persons for helping them in the sample preparations: Mr. Eduardo Martín, Mr. Enrique Oliver, Mrs. Silvia Gracia and Mrs. Teresa Rodríguez.

\section{REFERENCES}

Álvaro, J. and Vennin, E. 1998. Stratigraphic signature of a terminal Early Cambrian regressive event in the Iberian Peninsula. Canadian Journal of Earth Sciences, 35, 402 411.

Álvaro, J., Gozalo, R. y Liñán, E. 1993a. Bioestratigrafía del límite Cámbrico Inferior-Medio en Ateca (Cadena Ibérica Occidental, España). Revista Española de Paleontología, $\mathbf{n}^{\mathbf{0}}$ extr., 40-48.

Álvaro, J., Gozalo, R., Liñán, E. and Sdzuy, K. 1993b. The palaeogeography of the northern Iberia at the LowerMiddle Cambrian transition. Bulletin de la Société géologique de France, 164, 843-850.

Chernysheva, N. E. 1956. Paradoxididae. In: Materials of palaeontology. New families and genera. Trudy Vsesoyuzniy Nauchno-Issledovatelyskiy Geologichiy Institut (VSEGEI), New series, 12, 147-150. (In Russian).

Dies, M. E., Gozalo, R. y Liñán, E. 1999. Presencia de Kingaspis campbelli (King 1923) (Trilobita) en el Bilbiliense (Cámbrico Inferior) de Murero (Zaragoza). Temas Geológicos y Mineros, 26, 223-225.

Dies, M. E., Gozalo, R. y Liñán, E. 2001. Protolenus (Hupeolenus) Geyer 1990 (Trilobita) en el Bilbiliense (Cámbrico Inferior) de Jarque (Zaragoza, Cadenas Ibéricas). Seminarios de Paleontología de Zaragoza (SEPAZ), 5, 301-309.

Geyer, G. 1990. Die marokkanischen Ellipsocephalidae (Trilobita: Redlichiida). Beringeria, 3, 1-363.

Geyer, G. and Palmer, A. R. 1995. Neltneriidae and Holmiidae (Trilobita) from Morocco and the problem of Early Cambrian intercontinental correlation. Journal of Paleontology, 69, 459-474.

Geyer, G. and Shergold, J. 2000. The quest for internationally recognized divisions of Cambrian time. Episodes, 23, 188-195.

Gigout, M. 1951. Etudes géologiques sur la Méséta marocaine occidentale (arrière-pays de Casablanca, Mazagan et Safi). Notes et Mémoires du Service Géologique du Maroc, 86, 1-507.

Gil Cid, M. D. and Jago, J. B. 1989. New data on the Lower Cambrian Trilobites of Cortijos de Malagón (Spain). Estudios Geológicos, 45, 91-99.

Gozalo, R., Liñán, E. and Sdzuy, K. 1996. The Lower and Middle Cambrian of Murero and Villafeliche (West
Asturian-Leonese Zone. Western Iberian Chain). In: II Field Conference of the Cambrian Stage Subdivision Working Groups. International Subcommission on Cambrian Stratigraphy. Spain. 13-21 September 1996. Field Trip Guide and Abstracts (Eds. E. Liñán, J. A Gámez Vintaned and R. Gozalo). Universidad de Zaragoza, 73-80.

Hupé, P. 1953. Contributions à l'étude du Cambrien inférieur et du Précambrien III de l'Anti-Atlas marocain. Notes du Service Géologique du Maroc, 103 (1952), 1402.

King, W. B. R. 1923. Cambrian fossils from the Dead Sea. Geological Magazine, 60, 507-514.

Kobayashi, T. 1935. The Cambro-Ordovician Formations and Faunas of South Chosen. Palaeontology. Part III. Cambrian Faunas of South Chosen with a special study on the Cambrian Trilobite Genera and Families. Journal of the Faculty of Science, Imperial University of Tokyo, section 2, 4, 49-344.

Lendzion, K. 1972. Stratygrafia Kambru dolnego na obszarze Podlasia. Instytutu Geologiczny Biuletyn, 233 69-157.

Liñán Guijarro, E. 1978. Bioestratigrafía de la Sierra de Córdoba. Tesis doctorales de la Universidad de Granada, 191, 212 pp.

Liñán, E. and Gámez-Vintaned, J. A. 1993. Lower Cambrian palaeogeography of the Iberian Peninsula and its relations with some neighbouring European areas. Bulletin de la Société géologique de France, 164, 831842.

Liñán, E. y Gozalo, R. 1986. Trilobites del Cámbrico inferior y medio de Murero (Cordillera Ibérica). Memorias del Museo Paleontológico de la Universidad de Zaragoza, 2, 1-104.

Liñán, E. y Gozalo, R. 1999. Nuevos trilobites del Cámbrico Inferior de Aragón. In: 25 años de Paleontología aragonesa. Homenaje al Profesor Leandro Sequeiros (Eds. J. A. Gámez Vintaned y E. Liñán). Institución "Fernando el Católico", Zaragoza, 255-261.

Liñán, E., Fernández-Nieto, C., Gámez, J. A., Gozalo, R., Mayoral, E., Moreno-Eiris, E., Palacios, T. y Perejón, A. 1993a. Problemática del límite Cámbrico Inferior-Medio en Murero (Cadenas Ibéricas, España). Revista Española de Paleontología, $\mathbf{n}^{\circ}$ extr., 26-39.

Liñán, E., Perejón, A. and Sdzuy, K. 1993b. The LowerMiddle Cambrian stages and stratotypes from the Iberian Peninsula: a revision. Geological Magazine, 130, $817-$ 833.

Liñán, E., Sdzuy, K., Álvaro, J. J., Gámez Vintaned, J. A. and Gozalo, R. 1996. The Jarque section: Lower and Middle Cambrian West Asturan-Leonese Zone. Eastern Iberian Chain). In: II Field Conference of the Cambrian Stage Subdivision Working Groups. International Subcommission on Cambrian Stratigraphy. Spain. 13-21 September 1996. Field Trip Guide and Abstracts (Eds. E. Liñán, J. A. Gámez Vintaned and R. Gozalo). Universidad de Zaragoza, 57-72.

Lotze, F. 1929. Stratigraphie und Tektonik des Keltiberischen Grundgebirges (Spanien). Abhandlungen der Gesellschaft der Wissenschaften zu Göttingen, 
mathematisch-physikalische Klasse, n. F., 14, 1-320. [Traducción española de San Miguel de la Cámara, M. 1955. Estratigrafía y tectónica de las cadenas paleozoicas celtibéricas. Publicaciones extranjeras sobre Geología de España, 8, 1-313.]

Lotze, F. 1958. Zur Stratigraphie des spanischen Kambriums. Geologie, 7 (3-6), 727-750. [Traducción española de Gómez de Llarena, J. 1961. Sobre la estratigrafía del Cámbrico español. Notas y Comunicaciones del Instituto Geológico y Minero de España, 61, 131-164.]

Lotze, F. 1961. Das Kambrium Spaniens. Teil I: Stratigraphie. Akademie der Wissenschaften und der Literatur, Abhandlungen der mathematischnaturwissenschaftlichen Klasse, 1961 (6), 283-498 (1216). [Traducción española de Gómez de Llarena, J. 1970. El Cámbrico de España. Memorias del Instituto Geológico y Minero de España, 75, 1-256.]

Lotze, F. und Sdzuy, K. 1961. Das Kambrium Spaniens. Teil I: Stratigraphie. Akademie der Wissenschaften und der Literatur, Abhandlungen der mathematischnaturwissenschaftlichen Klasse, Wiesbaden 1961 (6), 238-498 (1-216); Teil II: Trilobiten. Akademie der Wissenschaften und der Literatur, Abhandlungen der mathematisch-naturwissenschaftlichen Klasse, 1961 (78), 499-690 (217-408).

Mansuy, H. 1912. Étude géologique du Yun-nan oriental. IIe Partie: Paléontologie. Mémoirs du Service géologique de l'Indochine, 1, $147 \mathrm{pp}$.

Matthew, G. F. 1887. Illustrations of the fauna of the St. John Group. No. IV. On the smaller-eyed trilobites of Division I, with a few remarks on the species of the higher divisions of the group. Canadian Record of Science, 2, 357-363.

Orlowski, S. 1964. Kambr srodkowy i jego fauna we wschodniej czesci gór swietokrzyskich. Middle Cambrian and its fauna in the eastern part of the Holy Cross Mts. Studia Geologica Polonica, 16, 1-94.

Pillola, G. L. 1990. Lithologie et Trilobites du Cambrien inférieur du SW de la Sardaigne (Italie). Implications paléobiogéographiques. Comptes Rendus de l'Académie des Sciences Paris, ser. 2, 310, 321-328.

Prado, C. de. 1855. Mémoire sur la géologie d'Almaden, d'une partie de la Sierra Morena et des Montagnes de Tolède. Bulletin de la Société Géologique de France, $2^{\text {ème }}$ Série, 12, 1-24, 182-204.

Richter, R. und Richter, E. 1941. Das Kambrium am Totem Meer und die älteste Tethys. Abhandlungen der senckenbergische naturforschenden Gessellschaft, 460, 1-50.
Richter, R. und Richter, E. 1948. Zur Frage des UnterKambriums in Nordost-Spanien. Senckenbergiana, 29, 23-39.

Rushton, A. W. A. and Powell, J. H. 1998. A review of the stratigraphy and trilobite faunas from the Cambrian Burj Formation in Jordan. Bulletin of The Natural History Museum (Geology Series), 54, 131-146.

Sdzuy, K. 1958. Neue Trilobiten aus dem Mittelkambrium von Spanien. Senckenbergiana lethaea, 39, 235-253.

Sdzuy, K. 1961. Das Kambrium Spaniens. Teil II: Trilobiten. Akademie der Wissenschaften und der Literatur, Abhandlungen der mathematisch-naturwissenschaftlichen Klasse, 1961 (7-8), 499-690 (217-408).

Sdzuy, K. 1971. Acerca de la correlación del Cámbrico inferior de la Península Ibérica. I Congreso HispanoLuso-Americano de Geología Económica, Sección 1 Geología, 2, 753-758.

Sdzuy, K. 1995. Acerca del conocimiento actual del Sistema Cámbrico y del Límite Cámbrico Inferior-Cámbrico Medio. In: Memorias de las IV Jornadas Aragonesas de Paleontología: "La expansión de la vida en el Cámbrico”. Libro homenaje al Prof. Klaus Sdzuy (Eds. J. A. Gámez Vintaned and E. Liñán). Institución "Fernando el Católico". Zaragoza, 253-263.

Sdzuy, K., Liñán, E. and Gozalo, R. 1999. The Leonian Stage (early Middle Cambrian): a unit for Cambrian correlation in the Mediterranean subprovince. Geological Magazine, 136, 39-48.

Termier, H. et Termier, G. 1950. Paléontologie Marocaine. Tome 2. Invertébrés de 1'Ere primaire. Fasc. 4: Annélides, Arthropodes, Échinodermes, Conularides et Graptolithes. Notes et Mémoires du Service Géologique du Maroc, 79, 1-279.

Weggen, K. 1955. Vorkommen und stratigraphischen Verhältnisse des Kambriums in den östlichen Montes de Toledo. Zeitschrift der deutschen geologischen Gesellschaft, 105, 572-573.

Westrop, S. R. and Landing, E. 2000. Lower Cambrian (Branchian) Trilobites and Biostratigraphy of the Haford Brook Formation, Southern New Brunswick. Journal of Paleontology, 74, 858-878.

Zamarreño, I. 1972. Las litofacies carbonatadas del Cámbrico de la Zona Cantábrica (NW de España) y su distribución paleogeográfica. Trabajos de Geología, Universidad de Oviedo, 5, 1-118.

Zamarreño, I., Vegas, R. y Moreno, F. 1976. El nivel carbonatado de los Navalucillos y su posición en la sucesión Cámbrica de los Montes de Toledo occidentales (Centro de España). Breviora Geológica Astúrica, 20, 56-64. 